Arab World English Journal (AWEJ) Volume 12. Number2 June 2021

DOI: https://dx.doi.org/10.24093/awej/vol12no2.28

Pp.414-423

\title{
Tailoring Potent Courses for ESP Learners: A Way to Better Fulfil their Demands
}

\author{
Fatma ZAGHAR \\ Department of English, Faculty of Foreign Languages \\ University of Oran 2 - Mohamed BEN AHMED - Oran, Algeria \\ Corresponding Author: tzafour@yahoo.com \\ El-Alia Wafaâ ZAGHAR \\ Department of English, Faculty of Foreign Languages \\ University of Oran 2 - Mohamed BEN AHMED - Oran, Algeria
}

Received: 4/29/2021

Accepted: 5/28/2021

Published:6/24/2021

\begin{abstract}
In this day and age, it is absolutely indispensable for acquiring competence in English to grapple with the real impediments and huge challenges of the modern epoch. The emergence of English as a global language is among the factors that could explicate its vitality and its expansion. The basic burden of making language courses more relevant to learners' needs resulted in the advent of languages for specific purposes movement, known in English Language Teaching circles as English for Specific Purposes. ESP then, has since its inception in the early 1960s become one of the most dynamic branches of applied linguistics in general, and of Teaching English as a Foreign Language in particular. To amass relevant data, a case study was conducted through a combination of a questionnaire, classroom observation, and informal interviews with language teachers and subject specialists. The main aim of this present paper is to precisely delineate the teaching/learning process of ESP in the department of Computer Sciences at the University of ORAN1 in Algeria, and the learners' attitudes towards this teaching. For this purpose, it is necessary to explore the utility of ESP as perceived by learners, and to address problems faced by instructors. The results indicate that the students have a positive attitude towards ESP and that their poor achievement was due to multiple reasons. This digest concludes by offering some suggestions and implications as remedial actions to the major confronted concerns.
\end{abstract}

Keywords: course design, ESP students, learners' attitudes, learners' demands, motivation, needs analysis

Cite as: ZAGHAR, F., \& ZAGHAR, E. W. (2021). Tailoring Potent Courses for ESP Learners: A Way to Better Fulfil their Demands. Arab World English Journal, 12 (2) 414-423. DOI: https://dx.doi.org/10.24093/awej/vol12no2.28 


\section{Introduction}

In the twenty-first century, the whole globe has become interconnected and narrow as English serves the purpose as a common language and a global one. It plays an eminent role in almost all the territories presently. In consequence, a good command of English in an alien language situation is the passport to social, scientific, economic, technological and educational growth, and the good user of English identifies himself as a successful and an integrated member when he covers a lot of ground of that language community. To satisfy those wants, more and more persons have extremely specific academic and professional motives for the betterment of their language skills. For these learners, usually adults, courses fall under the heading of English for Specific Purposes (ESP) whose aim was then to equip learners with a command of English in an efficient manner by basing courses on what students actually needed rather than teaching the whole language system (Woodrow, 2018).

\section{ESP Elemental Foundations}

This section offers an understanding of the major qualities and requirements of ESP. What is ESP?

ESP is known as a learner-centred approach to teaching English as a foreign language. It meets the demands of learners who need to learn English for use in their specific areas. English for specific purposes (ESP) refers to the teaching and learning of English as a second or foreign language where the goal of the learners is to use English in a particular domain (Paltridge \& Starfield, 2013). The ESP approach to language teaching began as a response to a number of practical concerns; especially to meet the needs of students who want English relevant to their field of specialism or to use it in their future career. In relation to that, Mackay and Mountford (1978) stated that "ESP is generally used to refer to the teaching of English for a clearly utilitarian purpose" (p.2). Thus, in the realm of ESP, the primary focus is upon the specific language appropriate to the target disciplines (areas of study) or occupations. Robinson (1991) writes to this effect "Students study English not because they are interested in the English language culture as such but because they need English for study or work purposes" (p.2). For Robinson, ESP learners study English for utilitarian reasons not in order to integrate in the Target-Language Community.

\section{ESP Traits}

In 1998, Dudley-Evans and St John noted that there has been considerable debate about the meaning of ESP. They modified Strevens' definition (1998) to postulate their own which makes a distinction between absolute and variable characteristics.

\section{The Absolute Characteristics of ESP}

1 - ESP is defined to meet specific needs of the learners.

2- ESP makes use of underlying methodology and activities of the discipline it serves

3- ESP is centred on the language appropriate to these activities in terms of grammar, lexis, register, study skills, discourse and genre.

\section{The Variable Characteristics of ESP}

1- ESP may be related to or designed for specific disciplines.

2- ESP may use, in specific teaching situations, a different methodology from that of General English. 
3- ESP is likely to be designed for adult learners, either at tertiary level institution or in a professional work situation. It could, however, be for learners at secondary school level.

4- ESP is generally designed for intermediate or advanced students.

5- Most ESP courses assume some basic knowledge of the language system.

The division of ESP into 'absolute' and 'variable' characteristics, in particular, could be helpful in resolving arguments about what is or is not ESP. In the definition they offered, Dudley-Evans and St John have removed the absolute features that ESP has in contrast with English for General Purposes (EGP) and added more variable aspects. Furthermore, they claim that ESP can be but is not necessarily concerned with a scientific discipline, nor does it target a certain age group or ability range.

In parallel, a practical suggestion for ESP teaching is given by Mc Donough (1984) when he affirms that English is "best identified as the distinction between language as a subject... and as a service" (p.5).

\section{Needs Analysis}

An important principle of ESP approaches to language teaching is that a well-founded educational program should be based on an analysis of learners' needs rather than developing a course around an analysis of the language. Procedures used to collect information about learners' needs are known as needs analysis. At its most basic, needs analysis involves finding out and interpreting information about what the learners know and can do and what they need to learn or do, so that the course will address them effectively.

Acknowledging its importance as a crucial quality of ESP course design, Mc Donough (1984) comments "The idea of analyzing the language needs of the learner as a basic for course development has become almost synonymous with ESP" (p.29). Hutchinson and Waters (1987) too admit the weightiness of needs analysis for ESP, but they add that "What distinguishes ESP from General English is not the existence of a need as such but rather an awareness of the need" (p.53).

Who is involved in Needs Analysis?

A needs analysis may be conveyed for a variety of users:

- Curriculum officers in the ministry of education, who may use the collected information to develop syllabuses, curriculums, and materials.

- Teachers who will teach from the curriculum.

- Learners who will be taught from the curriculum.

- Writers who are planning new textbooks.

\section{The Aims of Needs Analysis}

Needs analysis in language teaching provides the core information that is essential in establishing programs, it may be used for dissimilar purposes, for example:

- To determine the cause of performance deficiencies and potential solutions.

- To value the extent to which learners' needs are met by currently available programs and textbooks.

Richards (2005) identifies the following purposes for needs analysis: 
- To help determine if an existing course adequately addresses the need of potential students.

- To determine which students from a group are most in need of training in particular language skills.

- To identify a gap between what students are able to do and what they need to be able to do.

- To collect information about a particular problem learners are experiencing.

As a result, needs analysis is a vital facet of ESP course design, and its significance is acknowledged as a preliminary step in ESP teaching.

\section{ESP Course Design}

Course design refers to the planning of a course to achieve desired instrumental goals. The process entails identifying appropriate goals, choosing content consistent with the goals, selecting ways of accomplishing the goals, and assessing student learning in relation to the goals.

Hutchinson and Waters (1987) have defined a course as "an integrated series of teachinglearning experiences, whose ultimate aim is to lead the learners to a particular state of knowledge" (p.65). In ESP contexts, the course will take into account not only the subject area but the students (business, computer sciences, etc.) in terms of topics and themes, but also the lexical, semantic and structural aspects of the language features of that subject area.

Moreover, the functions and language forms that are more frequent in ESP must be identified. The goal aimed at is basically to bring students to a level of communicative capability that gives them the competence to function in their area of interest. Close, in Mc Donough's book, summarises the three necessary hierarchical stages through which an ESP course is built: "A foundation that could serve for any purpose (would refer to as a common core). A superstructure that could serve for any scientific purpose. A later superstructure that could serve for some specific scientific purpose" (as cited in Mc Donough, 1984, p.54).

Furthermore, developing a course requires that the teachers should ask questions about what the body of content, how best to impart knowledge to students, and how to assess what students are learning. The process of course development for the teacher is represented by Graves as follows:

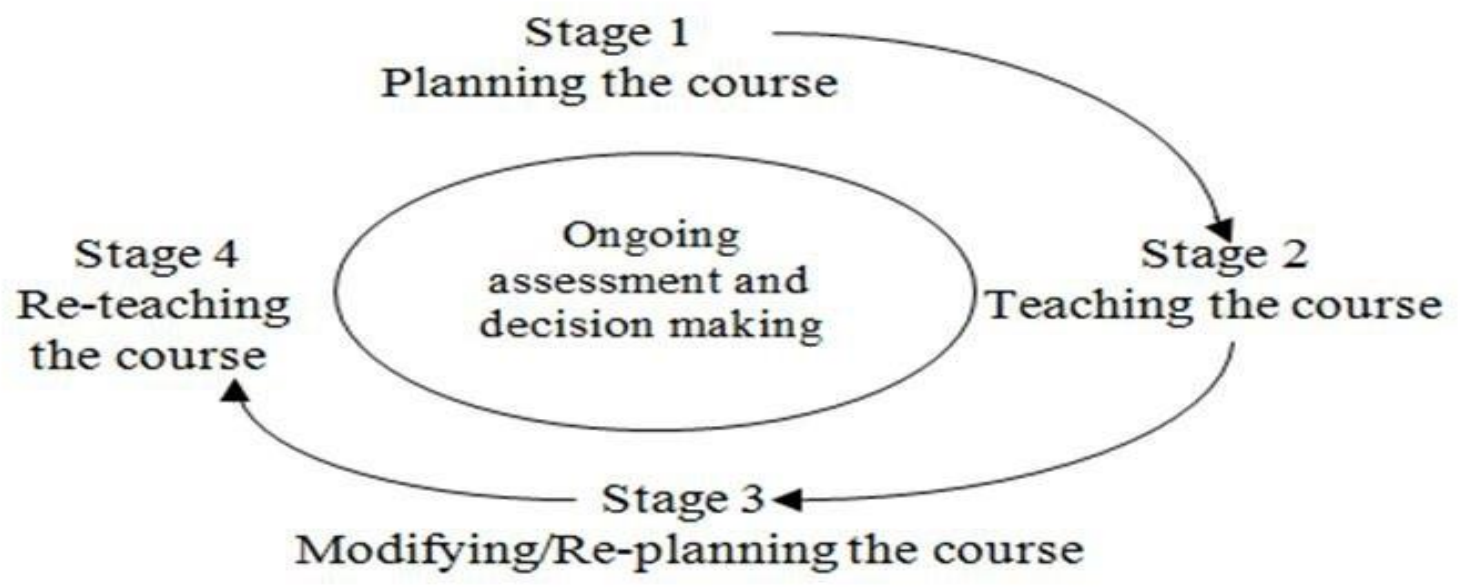

Figure 1. Process of course development for the teacher (Adapted from Graves, 2004, p.4) 
Consequently, course development includes planning a course, teaching it, and modifying the plan, both while the course is in progress and after the course is over (Graves, 2004). So, a well designed syllabus featuring strong and achievable learning objectives is the key to a successful course. It helps outlining what students are expected to know and be able to do.

A concise outline of a course of study is also the students' introduction to the teacher and to the course's subject matter, assignments, and activities.

\section{The Psychological Facets in ESP}

Teaching is a process which encompasses two participants, the teacher and the learner. It may be affected by various factors such as teacher's personality, classroom atmosphere, students' behaviour, motivation, etc. The latter is still being investigated by psychologists of education and linguists who concede that a lot is to be said about, while putting forward its importance in teaching and learning.

Affective factors interfere in the learning process as much as cognitive constituents do. Factors like attitudes, motivation and anxiety are to be taken into consideration owing to the role they play in promoting or obstructing learning in general and foreign language learning in particular. As far as the ESP context is concerned, these aspects of the learner's personality have a direct and capital influence on the ESP learner.

\section{Learner's Attitudes}

The learner's attitudes refer to the view he/she holds for learning basically and the foreign language specifically. Ultimately, successful learning seems to give a very significant place to the role of motivation. Without motivation, success in learning English or any other subject is unlikely. The attitude of learners who show poor motivation is described by Wright (1987) who asks "What are the symptoms of low motivation? Learners may exhibit a negative attitude to the subject you are teaching ...Attendance may fall off and learners who continue coming to class may be disruptive" (p.12). Through this description, Wright shows the negative effect of low motivation in the process of teaching and learning.

\section{Learner's Motivation}

Motivation is the internal force that makes an individual behave the way he does. As far as learning is concerned, motivation directs the human being to make efforts to succeed in learning. Gardner and Lambert (1972), the pioneers in research and writing on motivation sketch it out as "the combination of effort plus desire to achieve the goal of learning the language plus favourable attitudes towards learning the language" (as cited in Ellis, 2000, p.509). Thus, three factors are included in effective language learning: positive attitude, will to learn and effort. Motivation, then, can be either integrative resulting from the learner's positive attitudes towards the language and its target community and to be part of this group or instrumental aiming at reaching utilitarian reasons.

ESP learners are said to be instrumentally motivated towards learning English since they need it to benefit from the literature on computer science written in this language. The mastery of an international language like English is also required in the work sphere. Motivation in ESP is a 
fundamental personal factor acknowledged by a great number of theoreticians in the domain educational psychology as put by Ellis (2004):

Not surprisingly teachers recognize the importance of motivation, both with regard to the motivation that students bring to the language classroom (extrinsic motivation) and the motivation that is generated inside the classroom through the choice of instructional activities (intrinsic motivation). Similarly, motivation has attracted increasing attention from researchers, reflected in a growing number of theoretical models of L2 motivation and in consequent research studies (p.11).

Therefore, in the view of Ellis, the paramountcy of motivation as an influencing effective factor in the teaching/learning process is behind the richness of literature on this psychological topic.

\section{Thematic Scope}

This part seeks to explore the status of teaching ESP at the University of ORAN1 - Ahmed BEN BELLA - in the department of Computer Sciences, with reference to first year students. This population was composed of 147 learners (male and female) and five teachers who actively participated in this study. To probe more thoroughly this situation, the researchers have carried out a case study as a possible educational approach to accumulate valuable information through the utilization of diverse tools such as questionnaire, interview, and observation in order to reveal the most identified problems encountered during the ESP teaching/learning process in this institution.

\section{Methodology Design}

The teaching of ESP in the department of Computer Sciences has long been a problematic task. It seems to be hampered by some pedagogical and organizational barriers which prevent the effective teaching of English, for instance, the teachers' lack of training as language/ESP teachers, an absence of peer-coaching which may provide good opportunities for teachers to look at their teaching practices and to develop potential solutions.

As a remedial action, this study aims to address the following question:

- How is it possible to ameliorate the teaching of English in department of Computer Sciences at the University of ORAN1?

The authors propound a reconsideration of the entire teaching process with more focus on the learner's needs and the design of a more relevant syllabus that satisfies the student's demands.

To better depict the situation as it occurs in its natural environment, a case study approach was opted for. This powerful process provides suitable answers to an array of queries as purported by Yin (2009) who affirms that case studies are preferred in the following circumstances:

- When, how or why questions are being asked.

- When the researcher has little control over events.

- When the focus is on a contemporary phenomenon.

This approach, then, affords the investigator a tool to undertake exhaustive, comprehensible, quantitative and qualitative research.

In order to get the response that is most helpful to the investigation, a questionnaire was given to 147 students (male and female). Given its value as an effective technique for aiding the 
teacher get a real view of learner's needs and what issues should be stressed. In this respect, Richards (2005) discloses:

Questionnaires are one of the most common instruments used. They are relatively easy to prepare, they can be used with large numbers of subjects, and they obtain information that is relatively easy to tabulate and analyze. They can also be used to elicit information about many different kinds of issues, such as language use, communication difficulties, preferred learning styles, preferred classroom activities, and attitudes and beliefs (p.60).

Considered as one of the ways and required methods to explore the situation, classroom observation is utilised. It provides teachers with constructive feedback aimed to enhance their instructional techniques. It permits the researcher to know a lot about the area under study, to see the target group (computer sciences students) in its natural setting. The good research should be interesting, original, and should use all kinds of observations of specific events to uncover general facts (Mc Donough \& Mc Donough, 1997).

In order to assemble data with the purpose of ascertaining and evaluating the quality of instruction as well as to gain a sound knowledge from individuals, informal interviews were conducted with teachers to deeper investigate the encountered issues.

\section{Findings and Discussion}

This section highlights the major results obtained from this study.

Learners' Attitudes Towards English and Increased Desire to Learn it:

- The Students' Questionnaire:

Almost all the learners $(97,28 \%)$ showed a positive attitude towards learning English. They insisted on the necessity to reinforce their English courses through written assignments, homework and speaking practices. They also claimed that there exists a huge gap between their current ESP lessons and their immediate needs since a great emphasis is placed on developing the reading skills rather than improving the four language capabilities.

From the students' comments, the following needs can be identified:

- Writing scientific articles.

- Leading discussions and debates tightly related to their area of specialism in English and communicating with foreign engineers and specialists in computer sciences at the university, in the workplace and outside Algeria.

- Defending their vivas (Master and PhD) in English.

- Attending national and international conferences and lectures in English.

- Being able to read specialists' literature, academic journals and all related documents.

- Having a good control of English due to its desideratum to get relevant job opportunities and for pursuing academic studies.

\section{Teachers' Requirements for Specific Ongoing Training and Improved Teaching Practices:}

- Analysis of the Teachers' Informal Interviews:

The assessment of the teachers' interview revealed the following aspects:

- ESP teachers in the department gave elemental importance to the skill of reading to the detriment of the other language skills.

- The teachers stated that speaking and writing seem to be the domains in which students fail. 
- All instructors noticed that their learners have real difficulties in producing, whether in the written form or the spoken one, simple sentences.

- It should be mentioned that the skill of writing does not receive enough emphasis and this raises a kind of contradiction between the way ESP courses are taught and the way learners are evaluated since writing comes in the first position in tests and exams.

- The interview discloses that computer sciences students are not really given opportunities in their ESP classes to practise English at the oral and written levels.

- The teachers concluded that the use of workbooks and updated articles seems to be vital to increase the learners' interest in the target language and promote their language aptitudes.

- Teachers complained about the lack of availability of specialised textbooks at the library, the nothingness of relevant teaching materials as well as the inexistence of a suitable syllabus.

- The respondents indicated that the time devoted to ESP courses is far from being sufficient and from reaching the stated objectives that is why they suggested that extra hours are highly required to enhance the teaching/learning situation of English in the department.

- Large class sizes constituted a hard task for the informants and an obstacle that prevented them from easily ensuring their classes.

$-$

\section{The Students' Lack of Involvement in the Learning Process:}

- Classroom Observation:

On the basis of the examination of the data accumulated from class observation, some general statements regarding learners' needs and ESP practitioners' practices can be presented:

- Computer sciences students seem to learn better in a conducive atmosphere.

- They also desire to learn in a dynamic and autonomous language learning environment.

- Researchers have observed that pair work and group work are among the learning styles preferred by these students.

- A considerable number of students perceived that translation exercises are useful for them to improve their English proficiency.

- It should be highlighted that learners' attention and enthusiasm are upped when recent notions and latest discoveries related to their area of specialism are incorporated in their lessons.

\section{The Quest for A Fitting Change}

The analysis of the results unveiled the non-existence of an appropriate syllabus that suits the learners' needs in the department of computer sciences. This research showed that in order to meet the changing demands of these specific learners, it is recommended to plan a programme that gives due consideration to the learning objectives followed by the working out of a pertinent curriculum and the construction of special courses that respond to the learners' academic and vocational attainments. The possible suggestions which may attenuate some of the identified obstacles that computer sciences confront in their ESP courses comprise: the teacher, the learner, and the educational institution.

\section{The Teacher:}

The gathered data made known that the targeted students claimed that their ESP instructors have a serious lack of training and awareness of the special field they teach; therefore, the major recommendation should stress an ongoing support and specific training that allows teachers to keep current with the changing technology and classroom practices. The authors view that peer 
coaching is a useful professional procedure that aids educators to explore their own teaching methodologies and discuss their own observations. This strategy helps two or more professional colleagues work together to reflect on current practices; expand, refine, and build new skills; share ideas; teach one another, conduct classroom research; or solve problems in the workplace (Slater \& Simmons, 2001).

\section{The Learner:}

It is acknowledged that the learner has a basic role in guaranteeing the success of the learning experience. Therefore, ESP learners in the department of computer sciences are responsible for paying great attention to the variety of linguistic items they are taught to reinforce their knowledge, and acquire the necessary vocabulary and useful structures that they will use in their studies and later in their working surroundings. Being in an ESP context, these students approach English through an area with which they are already familiar with and that is relevant to them. As a consequence, they are combining subject matter and English language learning. This combination can be a motivating factor which will lead them to take on the responsibility of their own learning and to create indispensable elements which better satisfy their expectations.

\section{The Educational Institution:}

The department of computer sciences at the University of ORAN1 is an academic institution dedicated to education where officials, teachers and students interact with each other to produce effective change. This notion is well echoed by Morris (1994):

Schools are organizations and they develop a culture, ethos or environment which may be favorable or unfavorable to encouraging change and the implementation of innovations. A school with a relatively open climate, where the teachers collaborate with each other and where the principal and [senior teachers] are supportive of teachers, is more likely to try to implement a change (p.109).

ESP teachers claim that in this establishment the administration does not provide them with necessary and suitable materials and the encouraging conditions they need. It is also noticed from the gathered data that within this department the climate does not support innovation and there seems that little collegiality is observed, and no firm commitment to the university is shown. In order to enhance teacher development and learning standards in this department, university officials are recommended to encourage teachers to be more creative, raise their awareness, and promote their training and teaching circumstances.

\section{Conclusion}

On the basis of this study, it should be mentioned that there is no dubiety that the teaching of ESP in the department of computer sciences is not really well secured in respect to its vital importance and necessity for the learners to succeed in their field of speciality. The authors believe that the key foundation for students' accomplishments in English starts in middle and secondary school, and then must be nurtured and bolstered throughout university. The need for continuing training, the design of a convenient syllabus, a readjustment of teaching methods and classroom practices, a building of a real trust and assistance between teachers, and the establishment of a supportive classroom atmosphere are among the possible proposed remedies to the current encountered difficulties faced by teachers who ensure ESP courses. 


\begin{abstract}
About the Authors
Dr. Fatma ZAGHAR is an associate professor at the University of Oran 2 in Algeria. She received a PhD in Didactics. Her research and teaching interests focus on Teaching English as a Foreign Language (TEFL), English for Specific Purposes (ESP) Teaching, Intercultural Studies, and Educational Psychology. Currently, she is stressing new trends in Educational Technology. ORCID: https://orcid.org/0000-0003-1077-9719.
\end{abstract}

Dr. El-Alia Wafaâ ZAGHAR is an associate professor at the University of Oran 2 in Algeria. She holds a PhD in Didactics. Her basic research and interests accentuate Academic Writing, English for Specific Purposes (ESP), Linguistics, Research Methodology, Teaching English as a Foreign Language (TEFL) and Teacher Education.

ORCID: https://orcid.org/0000-0002-8185-3958.

\title{
References
}

Dudley-Evans, T. \& St John, M. (1998). Developments in ESP: A Multi-Disciplinary. Cambridge: Cambridge University Press.

Ellis, R. (2000). Second Language Acquisition. Oxford: Oxford University Press.

Ellis, R. (2004). Individual Differences in Second Language Learning. In Davies, A. \& Elder, C. (eds.), The Handbook of Applied Linguistics (pp. 525-551). USA: Blackwell Publishing Ltd.

Flyvbjerg, B. (2006). Five Misunderstandings about Case Research. Qualitative Inquiry, 12(2), 219-245. DOI: $10.1177 / 1077800405284363$

Gardner, R.C. \& Lambert, W.E. (1972). Attitudes and Motivation in Second Language Learning. Boston, MA: Newbury House Publisher.

Mackay, R. \& Mountford, A. J. (1978). The Teaching of English for Specific Purposes: Theory and Practice in Applied Linguistics and Language Study. London: Longman Group Ltd.

Mc Donough, J. (1984). ESP in Perspective: A Practical Guide. London and Glasgow: Collins ELT.

Mc Donough, J. \& Mc Donough, S. (1997). Research Methods for English Language Teachers. London: Arnold.

Morris, P. (1994). The Hong Kong School Curriculum. Hong Kong: Hong Kong University Press.

Hutchinson, T. \& Waters, A. (1991). English for Specific Purposes: A Learning-Centred Approach. Cambridge: Cambridge University Press.

Paltridge, B. \& Starfield, S. (2013). The Handbook of English for Specific Purposes. Chichester, UK: Wiley-Blackwell.

Richards, J.C. (2005). Curriculum Development in Language Teaching. New York: Cambridge University Press.

Robinson, P. (1991). ESP Today: A Practitioner's Guide. New York: Prentice-Hall International Ltd.

Slater, C.L. \& Simmons, D.L. (2001). The Design and Implementation of a Peer Coaching Program. American Secondary Education, 29(3), 67-76.

Woodrow, L. (2018). Introducing Course Design in English for Specific Purposes. New York: Routledge. Wright, T. (1987). Roles of Teachers and Learners. Oxford: Oxford University Press.

Yin, R. (2009). Case Study Research: Design and Methods ( $4^{\text {th }}$ ed.). Thousand Oaks, CA: Sage Publications. 